\title{
Transcranial Magnetic stimulation in Psychiatry: Past, Current and Future
}

\author{
Psikiyatride Transkraniyal Manyetik Uyarım: Geçmiş, Şimdi ve Gelecek
}

Burak Yulug ${ }^{1}$, Ahmet Aslan²*

1.Alanya Alaaddin Keykubat University, Department of Neurology and Neuroscience, School of Medicine, Antalya, Turkey

2.Alanya Alaaddin Keykubat University, Department of Orthopedic surgery, School of Medicine, Antalya, Turkey

\begin{abstract}
Transcranial Magnetic Stimulation (rTMS) is a novel non-invasive neuromodulation method applied via a coil to the skull surface of the patient stimulating relevant brain regions. Replicating data suggest the therapeutic role of repetitive transcranial magnetic stimulation (rTMS) in many psychiatric diseases though there are limited human neuroprotective data. Here we aimed to evaluate the therapeutic role of rTMS from a multifaceted perspective, including its effects on the neuroplasticity and neuroprotection processes. As a conclusion, rTMS seems to offer a potential for neuroprotective therapy.
\end{abstract}

Keywords: Transcranial Magnetic Stimulation; Neuroprotection; Psychiatric Diseases; Neuroplasticity

\section{öz}

Transkraniyal Manyetik Uyarım (TMU), hastanın kafatası yüzeyine bir bobin aracilığıla uygulanarak ilgili beyin bölgelerini uyaran yeni bir non-invaziv nöromodülasyon yöntemidir.insan çalışmalarında nöroprotektif etkisine dair kanıtlar sınırlı olsa da, yinelenen veriler, birçok psikiyatrik bozuklukta TMU' nın terapötik rol oynadığını düşündürmektedir. Bu yazıda nöroplastisite ve nöroproteksiyonun süreçler üzerindeki etkileri de dahil olmak üzere, çok yönlü bir bakış açısıyla TMU'nın terapötik etkisini araştırdık. Sonuç olarak, TMU, nöroprotektif tedavi için bir potansiyel sunuyor gibi görünmektedir.

Anahtar Kelimeler: Transkraniyal Manyetik Uyarım; Nöroproteksiyon; Psikiyatrik Hastalıklar; Nöroplastisite

Received: 21.08.2021 Accepted: 24.08.2021 Published (Online): 30.08.2021

*Ahmet Aslan, MD, Medical School of Alaaddin Keykubat University, Department of Orthopedics and Traumatology, Alanya/Antalya, Turkey., Turkey, +905056462411 ahmet.aslan@alanya.edu.tr

ORCID: 0000-0001-5797-1287

To cited: Yulug B, Aslan A.. Transcranial Magnetic stimulation in Psychiatry: Past, Current and Future.

Acta Med. Alanya 2021;5(2):; 107-108. doi:10.30565/medalanya.985758

\section{Introduction}

$\mathrm{H}$ istorically, the development of the TMS is has been shown to relate with the discovery of higher brain functions involving the unique topographical organization ability of the brain 1 . Magnetic stimulation, in other words, transcranial magnetic stimulation (TMS), is applied via a coil to the skull surface of the patient. Faraday firstly discovered the mechanism of TMS based on a simple principle of electromagnetic stimulation: The magnetic field derived from the electrical energy may, in turn, induce a secondary electric field that stimulates relevant brain regions. With modern transcranial magnetic stimulation development, TMS was a preferred method in many neurology and psychiatric disciplines 1 .

Basics and Clinical Applications 
Since $2008 \mathrm{r}$ T MS is an FDA (Food and drug administration) approved anti-depressant therapy in the United States. Furthermore, TMS has also been suggested to treat several other psychiatric diseases such as mania, OCD and schizophrenia. Therapeutically, there are two basic forms of TMS applications. The single-pulse TMS is used primarily for scientific and diagnostic purposes, while the repetitive TMS ( $r T M S$ ), consisting of repetitive pulses, is used mainly for therapeutic purposes. Also, different frequencies of rTMS have divergent effects. For instance, High-frequency rTMS ( $>5 \mathrm{~Hz}$ ) increases the cortical excitability , while lower frequencies $(<5 \mathrm{~Hz})$ decrease the motor excitability2. As mentioned above, rTMS is a preferred therapeutic method in the psychiatry discipline, especially when it comes to depression. The major advantage of this novel method is that it is not painful and does not require anaesthesia like other invasive stimulation methods, such as electro-convulsive therapy2,3. Furthermore, TMS does not alter consciousness, and technically it can penetrate the scalp, skull and brain cortex without inducing seizure activity1,2. Shortly, TMS is a safe, non-invasive and well-tolerated therapy method with very mild side effects, including mild headaches responding well to simple analgesics.

\section{Alternative Mechanisms}

Although the mechanism of its action seems mechanistic, many effects could not be simply explained with its stimulation effect on the cortex. For instance, many experimental studies have revealed that TMS might exert a neuroprotective and neuroplasticity inducing effect in addition to its anti-depressant effects3,4,5. For instance, rtMS (at high frequencies) induced neuronal plasticity similar to many anti-depressants suggesting that rTMS's anti-depressant effects might also involve restoring the impaired neuroplasticity process in depression6. Further neurochemistry and neurobiology studies elucidating the underlying mechanisms of the TMS finally showed that TMS might not only change the electrical activity but also lead to some critical changes in critical anti-depressant and neuroprotective molecules7. For instance, in several animal and human studies, BDNF, a well-known procognitive, anti-depressant and neuroprotective molecule, is increased after rTMS6,7. Since no cognitive side effects are described with rTMS, this opened a new window of the therapeutic role of ATMs in neurodegenerative diseases such as Alzheimer's and Parkinson's Disease8. Considering the role of neurodegeneration also in some psychiatric diseases, rTMS might be a novel tool with its additional neuroprotective effect. Although there are no conclusive human studies in this respect, animal data, including many psychiatric neurodegeneration models, are rapidly replicating $6,7,8$.

Conclusion: TMS is a novel tool for many neurological and psychiatric diseases. Beyond the time and location of stimulation, TMS can also modulate brain chemistry and network activity, offering the potential for neuroprotective therapy.

Conflict of Interest: No conflict of interest was declared by the authors.

Funding sources: The authors declared that this article received no financial support

\section{REFERENCES}

1. Eschweiler G.W. (2003) Entwicklung der transkraniellen Magnetstimulation (TMS) In: Eschweiler G.W., Wild B., Bartels M. (eds) Elektromagnetische Therapien in der Psychiatrie. Steinkopff, Heidelberg. https://doi.org/10.1007/978-3-642-57370-5_16

2. Facharztwissen Psychiatrie, Psychosomatik und Psychotherapie (2017). Frank Schneider. Springer-Verlag GmbH Deutschland. https://doi.org/10.1007/978-3$662-50345-4$

3. Yulug B. Neuroprotective treatment strategies for poststroke mood disorders: A minireview on atypical neuroleptic drugs and selective serotonin re-uptake inhibitors. Brain Res Bull. 2009 Sep 28:80(3):95-9. doi: 10.1016/j.brainresbull.2009.06.013. Epub 2009 Jul 1. PMID: 19576272.

4. Caglayan B, Kilic E, Dalay A, et al. Allyl isothiocyanate attenuates oxidative stress and inflammation by modulating $\mathrm{Nrf} / \mathrm{HO}-1$ and $\mathrm{NF}-\mathrm{kB}$ pathways in traumatic brain injury in mice. Mol Biol Rep. 2019;46(1):241-250. doi:10.1007/s11033-018-4465-4

5. Lapchak, Paul A., and John H. Zhang, eds. Neuroprotective therapy for stroke and ischemic disease. Switzerland: Springer International Publishing, 2017. doi: 10.1007/978-3-319-45345-3

6. Yulug B, Hanoglu L, Tavli AM, Yılmaz NH, KIlıc E. The Brain Protective Effect of rTMS (Repetitive Transcranial Magnetic Stimulation) in Depression: A Mini-Review in Animal Studies. Med Chem. 2016;12(6):500-505. doi:10.2174/1573406411666 151005110321

7. Yuluğ B, Ozan E, Kilic E. Brain-derived neurotrophic factor polymorphism as a genetic risk for depression? A short review of the literature. J Neuropsychiatry Clin Neurosci. 2010 Winter;22(1):123.E5-6. doi: 10.1176/jnp.2010.22.1.123.e5

8. Yulug B, Hanoglu L, Khanmammadov E, et al. Beyond The Therapeutic Effect of rTMS in Alzheimer's Disease: A Possible Neuroprotective Role of Hippocampal BDNF? : A Minireview. Mini Rev Med Chem. 2018;18(17):1479-1485. doi:10.2174/ 1389557517666170927162537

\begin{tabular}{|l|l|}
\hline Author / ORCID & Authorship Contrubition \\
\hline $\begin{array}{l}\text { Burak Yuluğ } \\
0000-0002-9704-6173\end{array}$ & $\begin{array}{l}\text { Consept and design, literature } \\
\text { review, manuscript writing, final } \\
\text { approval. }\end{array}$ \\
\hline $\begin{array}{l}\text { Ahmet Aslan } \\
0000-0001-5797-1287\end{array}$ & $\begin{array}{l}\text { Interpretation, critical review, } \\
\text { final approval. }\end{array}$ \\
\hline
\end{tabular}

